\title{
DYNAMICS OF SOIL ORGANIC CARBON FRACTIONS UNDER DIFFERENT LAND MANAGEMENT IN WET TROPICAL AREAS
}

\author{
Ermadani $^{1}$, Hermansah ${ }^{2}$, Yulnafatmawita ${ }^{2}$ and Auzar Syarif ${ }^{3}$ \\ ${ }^{1)}$ Graduate Program of Agricultural Sciences, Andalas University, Padang, Indonesia \\ ${ }^{2)}$ Department of Soil Science, Faculty of Agriculture, Andalas University, Padang, Indonesia \\ ${ }^{3)}$ Department of Agronomy, Faculty of Agriculture, Andalas University, Padang, Indonesia \\ Email:_ermadani_unja@yahoo.com
}

\begin{abstract}
Karbon (C) organik tanah yang merupakan bagian utama dari bahan organik tanah mengalami penurunan sebagai akibat perubahan-perubahan penggunaan lahan dari kondisi alami menjadi lahan-lahan pertanian. Penurunan $\mathrm{C}$ organik tanah menjadi semakin besar karena masukan bahan organik yang rendah dan bila penurunan ini. berlangsung terus menerus maka pada akhirnya menyebabkan degradasi tanah. Artikel ini membahas peranan, dekomposisi dan struktur dari bahan organik tanah dalam hubungannya dengan dinamika fraksi $\mathrm{C}$ organik tanah pada pengelolaan lahan yang berbeda di daerah tropis basah. Perubahan penggunaan dan pengelolaan lahan menyebabkan terjadinya perubahan $\mathrm{C}$ organik total dan fraksi-fraksi $\mathrm{C}$ organik labil dan stabil tanah. Beberapa penelitian telah menunjukkan bahwa fraksi $\mathrm{C}$ organik labil seperti $\mathrm{C}$ organik partikulat lebih responsif terhadap perubahan-perubahan dari pengelolaan tanah dan merupakan suatu indikator yang sensitif dari kualitas tanah. Disamping itu fraksi $\mathrm{C}$ organik stabil seperti asam humat yang mengalami perubahan karena praktek-praktek pengelolaan tanah dapat digunakan untuk menilai kapasitas potensial tanah sebagai penyimpan karbon. Perubahan-perubahan penggunaan lahan dan pengelolaan tanah mempunyai pengaruh negatif dan positif terhadap $\mathrm{C}$ organik total, fraksi $\mathrm{C}$ organik labil (C organik partikulat) dan fraksi $\mathrm{C}$ organik stabil (asam humat). Praktek-praktek pengelolaan yang dapat mempertahankan dan memperbaiki fraksi-fraksi $\mathrm{C}$ organik tanah meliputi sistem agroforestri, aplikasi pupuk organik, mulsa dan pengembalian sisa tanaman ke dalam tanah. Fraksi $\mathrm{C}$ organik partikulat dan asam humat menunjukkan perubahan-perubahan yang lebih besar dibandingkan $\mathrm{C}$ organik total akibat perubahan-perubahan penggunaan lahan dan praktekpraktek pengelolaan tanah di daerah tropis basah.
\end{abstract}

Key words : Fraksi C organik, penggunaan lahan, tropis basah

(C) 2018 Ermadani Ermadani, Hermansah Hermansah, Yulnafatmawita, Auzar Syarif

\section{INTRODUCTION}

Soil organic carbon (SOC) constitutes both a source and sink for nutrients (Bationo et al., 2007) and determines soil fertility, productivity, sustainability of agriculture ecosystem (Craswell and Lefroy, 2001) and also represents the potential stabilization or degradation of the soil resource by different land management (Handayani et al., 2012). Soil organic matter (SOM) consists of about $45-60 \%$ of its mass as SOC (Lal, 2016). In soil and plant ecosystem, SOM as main soil component closely relates to soil characteristics and processes occurring in soils (Chen et al., 2004).

Soils in tropical areas generally have experienced a reduction of organic matter and are susceptible to degradation, where some have been degraded as a result of a change from natural condition to agricultural uses with poor management (Craswell and Lefroy, 2001). Maintaining SOM, especially in tropical areas has been relatively difficult because of rapid decomposition of organic matter (Anda et al., 2010). 
Various types of land use and management have affected SOM fraction. This relates to SOM input and decomposition process occurring in different environments. Practices in conservational soil tillage, such as no-tillage (Quincke et al., 2007), organic farming and agroforestry (Handayani et al., 2012) can ameliorate SOM and other soil properties. High rainfall and temperature in tropical rainforest enable the addition of soil organic C (SOC) from plant debris and roots which are accompanied with high decomposition rate by microorganisms (Kursten and Burschel, 1993). High rainfall in wet tropical areas also encourages rapid plant growth (Ludwig et al., 1997). However, environment condition of tropical areas has currently deteriorated because of natural forest damage for crop agricultural land, plantation and other uses (Craswell and Lefroy, 2001). Soils in the tropics generally have relatively low SOM in which it was around $1.4 \%$ (Anda et al., 2010). In addition, Ai Dariah et al., (2012) reported that total organic $C$ in soils in Ciampea Village, Bogor Regency, and Pangandaraan Village, Ciamis Regency were $1.41 \%$ and $0.72 \%$, respectively. Soils with total organic $\mathrm{C}$ less than $2 \%$ are categorized as degraded soils (Greenland et al. 1975; Lal, 2004; Ai Dariah et al., 2012).

In general, determination of SOM content is based on total organic C. Soil organic $\mathrm{C}$ can be categorized into several fractions with different stability rate (Jagadamma et al., 2010). Measuring total organic $\mathrm{C}$ is not a sensitive indicator of changes on soil quality so that using procedures that can extract labile fractions can be specifically a useful approach to characterize soil organic $\mathrm{C}$ as a result of different soil management (Patricia et al., 2011). The labile fractions are made up of materials in transition between fresh plant residues and stabilized organic matter (Verma et al., 2013). Conversely, stabile fraction of SOM consists of organic materials that are highly resistant to microbial decomposition (Haynes, 2005). Labile organic fraction is easily mineralized with residence time around a month to a year (Krull et al., 2003), while stabile organic fraction is an intermediate fraction with the turnover rate from decade to hundred years (Bruun et al. 2007). The fraction of labile SOM can give a sensitive response on changes of land use and management practices (Wang and Wang, 2011). Several labile organic $\mathrm{C}$ fractions include extractable water $\mathrm{C}$, permanganate oxidizable (Haynes, 2005), and particulate organic C (POC) (Six et. al., 2002). Particulate organic $\mathrm{C}$ is a labile intermediate in the soil organic matter assortment ranging from fresh organic materials to humified SOC (Sreekanth et al., 2013). This organic matter C fraction may be quickly decomposed, thus constituting a fragile $\mathrm{C}$ reserve in the soil (de Figueiredo et al., 2010). Fractions of labile organic matter can be considered as good indicators of soil quality that affect soil function with specific ways and more sensitive to changes in soil management practices (Haynes, 2005). Additionally, soil C in its stable form responds gradually to agricultural management changes (Gollany et al., 2010).

This paper aims to describe the role, structure, and decomposition as well as dynamics of soil organic $\mathrm{C}$ fractions in relation to changes in soil use in wet tropical areas. Soil labile organic $\mathrm{C}$ fraction selected is particulate organic C fraction $(>53 \mu \mathrm{m})$ (Six et al., 1998; Cambardella and Elliott, 1992), while stabile organic $\mathrm{C}$ fraction is humic acid. This report is made up from studies that are mainly focused in the wet tropical areas. Additionally, several studies in subtropical and temperate areas are included as a comparison.

\section{THE ROLE OF SOIL ORGANIC MATTER}

Soil organic matter has a key role in sustainable soil management. Soil properties and process in the soil influenced by SOM include bulk density, temperature, structure, biological activity and nutrient availability (Haynes, 2005). Additionally, the content of SOM gives a positive contribution to the quantity of $\mathrm{C}$ and $\mathrm{N}$ that can be rapidly mineralized into $\mathrm{NH}_{4}{ }^{+}$and $\mathrm{NO}_{3}{ }^{-}$(Funakawa et al., 2009). 
Yulnafatmawita et al., (2013) reported that enhancement of SOM by application of Tithonia diversifolia, Chromolaena odorata, and Gliricidia sepium was also followed with the increases of aggregation percentage and aggregate stability index after three months incubation. Controlling the aggregate stability of soils by SOC occurs through binding primary particles with organic binding agents such as particulate organic matter composed of roots, fungal hyphae and fungal exudates such as polysaccharides and glomalin (Tisdall and Oades, 1982; Sreekanth, et al., 2013). In comparison to SOC, POC possesses a more positive effect on aggregate stability because aggregate formation was directly correlated to root-residue decay and POC dynamics under no-tillage practices and in undisturbed soils (Gale et al., 2000).

The POM functions as a primary energy source for heterotrophic microorganisms and a reservoir of labile $\mathrm{C}$ (Gregorich et al., 2006). Furthermore, particulate fraction has a role as a cementing agent in the stabilization process of macro aggregates and as the protection of organic matters inside aggregates (Six et al., 2002). Soil aggregates are formed through flocculation of clay colloids and cementation process by organic and inorganic matters (Jimenez and Lal, 2006).

Humic substances have a very complex biological activity, depending on its origin, molecular size, chemical characteristics, and concentration (Muscolo et al., 2006). Several mechanisms of organic matter stabilization might be governed by humic substances and have close relations to the capacity of the soil to store C (Bonifacio et al., 2011). Humic substances play a very important role in improving soil buffering capacity, increase moisture retention, and supply plants with available micronutrients (Guimaraes et al., 2013). The contribution of the humic acid fraction to cation exchange capacity (CEC) is through generating negative charges in soil (Valladares et al., 2007).

\section{STRUCTURE AND DECOMPOSITION OF SOIL ORGANIC MATTER}

Soil organic matter comprises soil biota, plant and animal tissues at different decomposition stages (Craswell and Lefroy, 2001). Soil organic matter is a heterogeneous mixture of materials consisting of fresh plant and microbial residues to relatively inert compound, with turnover rates measured in millennia (Verma et al., 2013). Decomposition of soil organic matter closely relates to humification, mineralization, dynamic and stabilization of soil organic matter (Zech et al., 1997). Chemical characteristic of plant residues such as $\mathrm{C} / \mathrm{N}$ ratio, $\mathrm{N}$, lignin and polyphenol concentration can affect decomposition rate (Wang et al., 2004). Residues with high $\mathrm{C} / \mathrm{N}$ ratio generally decompose slowly compared to those with a lower $\mathrm{C} / \mathrm{N}$ ratio and then plant residue with a higher $\mathrm{N}$ content experiences high decomposition rate and releases high nutrients (Kumar and Goh, 2000).

Decomposition of plant residue occurs in two main phase, where $70 \%$ of the $\mathrm{C}$ residue lose as $\mathrm{CO} 2$ and the following phase is lower decomposition phase on a more resistant fraction (Wang et al., 2004). The decomposition rate of SOM highly varies and takes place continuously on easily decomposed and very stable component (Quincke et al. 2007). Labile SOM decays more easily by soil microbe and more rapidly loses as a result of soil tillage compared to humic substances (Grandy et al., 2006).

The composition of decomposing microbes varies during decomposition process of residue. In composting process, bacteria are predominant in the initial phase, while fungi are dominant in the following phase (Cahyani et al., 2002). Mineralization of SOM releases nutrients to the soil which are available for the plant, converted to unavailable forms, loss to the atmosphere and leached (Blair et al., 1995).

The chemical structure of soil organic matters is determined mainly by the chemical composition of the $\mathrm{C}$ inputs and the environment (Baldock et al., 1992). Organic material sources with low quality contain high soluble polyphenol and lignin which have long 
decomposition time and give the contribution to soil organic $\mathrm{C}$ raise (Palm et al., 2001). Cellulose and lignin constituents of organic matter are recognized to be relatively resistant against microbial degradation so that organic matter in soils can be replenished and preserved by such C inputs (Anda et al., 2010). In a study on chemical changes of plant residue into SOM and its existence inside aggregate fraction in wet tropics Hawai, Steward et al., (2011) found that soils under fern vegetation Cheirodendron trigynum (species with rapid decomposition) contained more lipid composed of cutin and suberin, while soils under Dicranopteris linearis vegetation (species with low decomposition) contained aromatic compound originating from more lignin.

According to Ahn et al., (2009) there are two factors that are possibly interconnected in determining the bioavailability of SOM. Firstly, chemical availability, which is frequently considered as labiality is affected by the chemical composition of SOM related to the capability of microbial exocoenzymes to fragment organic polymers into smaller components in a dissolved form that can pass through microbial cell walls. Such compounds pools as carbohydrates and proteins are regarded as extremely labile, whereas lipids, lignin, and humic substances are relatively chemically intractable. Secondly, physical availability refers to the physical location of SOM. Soil organic matter that is fixed within mineral aggregates or sorbed within small pores may be protected from enzymatic attack and therefore be essentially biologically nonavailable (Six et al., 2002). Labile SOM is a quickly reactive organic matter fraction, which makes available energy and nutrients for soil micro-organisms and releases part of the nutrients for plant utilization. It provides shortterm organic matter turnover during the year, in which its half-life is between days and few years (Strosser, 2010).

\section{EFFECT OF LAND USE AND MANAGEMENT PRACTICES ON SOIL ORGANIC C FRACTIONS}

https://doi.org/10.25077/jsolum.15.1.26-39.2018
Dynamics of SOC is affected by numerous factors of which among are land use types and management practices in which decomposition and mineralization process could reduce SOC while the increasing SOC could occur by biomass input. Wet tropical rainforest constitutes one of main terrestrial $\mathrm{C}$ storage sources (Smiley and Kroshel, 2008). However, conversion of natural forest into agricultural land uses brings about a reduction in soil organic $\mathrm{C}$ (SOC) content over time, because of escalating mineralization rates stimulated by a rise in soil temperature (Pandey et al., 2010). In tropical and temperate regions, soil temperature in the exposed lands after forest clearing increases, thereby stimulating biological activity, causing an increase of $\mathrm{NH}_{4}{ }^{+}$ from SOM (Piccolo et al., 1994; Nunan et al., 2000).

Continuous SOM loss as a result of agricultural production has been a critical problem in most tropical soils ((Islam and Weil, 2000). Pandey et al., (2010) reported that in a wet tropical area, India with an average $3000 \mathrm{~mm}$ year ${ }^{-1}$ rainfall, where soils were Entisols, sandy loam, the highest quantity of SOC loss was $1430 \mathrm{~kg}^{-1} \mathrm{ha}^{-1}$ year-1 in grassland (6 years) and the lowest was 127 $\mathrm{kg} \mathrm{ha}^{-1}$ year $^{-1}$ in home garden ( 30 years). This happened because $\mathrm{C}$ output in grassland was much greater than $\mathrm{C}$ input.

In Indonesia, several studies on changes of total organic $\mathrm{C}$ as conversion of natural forest into agricultural land and other uses have been conducted. Yonekura et al. (2010) reported that total organic C in soil 0-8 $\mathrm{cm}$ depth had undergone a decrease due to conversion of natural forest in Amborawang and Batuah East Kalimantan Province into grassland (Imperata cylindrica), in which organic C in natural forest was $2,06 \%$, while in grassland after 10 years conversion contained $1,94 \%$ total organic $\mathrm{C}$ and grassland after 22 years was $1,48 \%$, thereby decreasing in total organic $\mathrm{C}$ as much as $6 \%$ and $28 \%$ respectively. The difference in total organic $\mathrm{C}$ between forest ecosystem and agroecosystem is also found in Danube lowland Slovak, temperate climate, in which the contents of 
total organic $\mathrm{C}$ are $2,6 \%$ and $1,8 \%$ respectively (Tobiasova and Miskolczi, 2012). Continuous land uses for agricultural activities without adequate organic matter inputs also result in a decrease in SOM. A study done by Widjanarko et al., (2012) showed that total SOC of cassava monoculture less than 10 years was $2.06 \%$, and then in 30 years cassave monoculture, total SOC was $0.70 \%$, so that reduction in total SOC was $66 \%$.

The content of soil organic matter (SOM) can also be used as an indicator of soil quality improvement. Setyawan et al., (2011) reported that in degraded soils $(0-3 \mathrm{~cm})$ of mine sites the content of SOC was relatively high, $\quad 52-130 \mathrm{~g} \mathrm{~kg}^{-1}$ after 7 years of rehabilitation, in which the soils underwent a relatively rapid recovery in tropics Kelian East Kalimantan with $3.500 \mathrm{~mm}$ year $^{-1}$ rainfall. Hermansah et al., (2010) reported that the total SOC in the $0-10 \mathrm{~cm}$ soil layer in mixed garden, cinnamon plantation, and cacao plantation was $7.01 \%, 5.73 \%$ and $4.80 \%$ respectively, in which the high content of organic $\mathrm{C}$ of Inceptisols in these various land uses in Pauh, Padang was caused by the high input of organic materials coming from clearing grass and underbrush growing under the mature plants and then the derived biomass left in soil surface underwent decomposition.

Various vegetations such as Tithonia diversifolia, Chromolaena odorata, and Gliricidia sepium growing well in wet tropical soils can be used as organic materials input to elevate SOM. Yulnafatmawita et al., (2013) found that application of $C$. odorata, $G$. Sepium and $T$. diversifolia to Ultisols (very fine clay texture) Limau Manis Padang increased SOM from $1.23 \%$ to $2.9,2.88$ and $3,06 \%$ respectively after three months incubation. A study on the application of animal manure, legume residue and chemical fertilizer carried out by Amusan and Adetunji (2013) showed that addition of animal manure and legume residue increased SOM, in which combined application of $5 \mathrm{tha}^{-1}, 100 \mathrm{~kg} \mathrm{~N} \mathrm{ha}{ }^{-1}$ and $5 \mathrm{t} \mathrm{ha}^{-1}$ legume residue resulted in an increase in SOC from $15.7 \mathrm{~g} \mathrm{~kg}^{-1}$ to $21.4 \mathrm{~g} \mathrm{~kg}^{-1}$, thus increasing $36.3 \%$ of SOC. However, the singular application of $\mathrm{N}$-fertilizer or $\mathrm{P}$ fertilizer over the three years of study caused a decrease of SOM, while a slight increase of SOM occurred by the singular application of legume residue. This demonstrates that soils in the tropical climate which are planted and fertilized with inorganic fertilizer continuously can deplete SOC leading to degradation and fertility loss over time.

Table 1. Distribution of total SOC (\%) in agroforestry system di Palolo, Central Sulawesi

\begin{tabular}{ccccc}
\hline Age (year) & $0-15 \mathrm{~cm}$ & $15-30 \mathrm{~cm}$ & $30-60 \mathrm{~cm}$ & $60-100 \mathrm{~cm}$ \\
\hline 2 & 1.63 & 1.36 & 1.04 & 0.46 \\
2,5 & 1.50 & 1.16 & 1.16 & 0.37 \\
3 & 1.94 & 1.53 & 1.14 & 0.41 \\
4 & 1.35 & 1.15 & 0.86 & 0.47 \\
5 & 1.93 & 1.23 & 1.11 & 0.56 \\
9 & 1.26 & 1.10 & 1.07 & 0.48 \\
12 & 1.91 & 1.80 & 1.14 & 0.35 \\
15 & 2.76 & 1.41 & 1.26 & 0.58 \\
\hline
\end{tabular}

Sumber: Smiley and Kroschel (2008)

Conversion of natural forest in National Park, Lore Rindu Central Sulawesi into maize field and agroforestry after less than 10 years results in a reduction in SOC by $29 \%$ and $26 \%$ in $0-10 \mathrm{~cm}$ depth and by $7 \%$ and $8 \%$ in 30-40 cm depth, respectively (Dechert et al.,
2004). However, the agroforestry system can represent a sustainable system by which sequestration of organic $\mathrm{C}$ can be larger. Smiley and Kroschel (2008) reported that at 015 soil depth in agroforestry system (cacaoGliricidia) there was a tendency in improving 
SOC in which in year two the content of SOC was $1.63 \%$ and then after 15 years SOC increased to $2.76 \%$, thereby increasing SOC by $69 \%$ (Table 1). In addition, in Table 1 it can be seen that the content of SOC decreased with deeper soil depth. This may have been as a result of higher biomass accumulation in the soil surface rather than in deeper soil layers. Reforestation also can boost $\mathrm{C}$ sequestration and soil fertility in degraded lands in tropics, in which increased biomass input is followed by increases in total organic $\mathrm{C}, \mathrm{N}$, and $\mathrm{P}$ (Sang et al., 2013).

Beside of total organic $C$, labile organic $\mathrm{C}$ fraction was also affected by differences in land use types. Sreekanth et al., (2013) reported that land use types with regard to changes and intensity of activities have had negative impact on the carbon pool both the total and particulate organic $\mathrm{C}$, where POC is more sensitive and an earlier indicator than SOC for land disturbances and soil carbon changes for short-term studies in grassland ecosystems. Particulate organic C positively correlates to dry weight of the plant, $\mathrm{N}$ concentration and $\mathrm{N}$ uptake by cassava plant (Widjanarko et al., 2012). Differences in SOC fractions in Ultisols (silty loam) on various land uses were reported by Handayani et al., (2012).

Table 2. Soil organic $\mathrm{C}$ fraction and $\mathrm{N}$ on different land use in Bengkulu Province, Sumatera, Indonesia

\begin{tabular}{|c|c|c|c|c|c|}
\hline Land use & $\begin{array}{c}\text { Total } \\
\text { organic C } \\
\left(\mathrm{g} \mathrm{kg}^{-1}\right)\end{array}$ & $\begin{array}{l}\text { Total N } \\
\left(\mathrm{g} \mathrm{kg}^{-1}\right)\end{array}$ & $\begin{array}{c}\text { Inorganic N } \\
\left(\mathrm{mg} \mathrm{kg}^{-1}\right)\end{array}$ & $\mathrm{C} / \mathrm{N}$ ratio & $\begin{array}{c}\text { Particulate } \\
\text { organic C } \\
\left(\mathrm{g} \mathrm{kg}^{-1}\right)\end{array}$ \\
\hline Grassland (Imperata cylindrica) & 29,95 & 2,09 & 15,26 & 14,33 & 3,87 \\
\hline Cassava & 26,20 & 2,10 & 10,32 & 13,10 & 4,46 \\
\hline Banana & 28,15 & 2,35 & 17,32 & 11,97 & 4,85 \\
\hline Legume & 35,61 & 2,95 & 31,78 & 12,07 & 8,89 \\
\hline Agroforestry & 37,23 & 2,85 & 27,52 & 13,06 & 9,69 \\
\hline
\end{tabular}

Source: Handayani et al. (2012)

The data on Table 2 shows that the lowest content of total SOC is found in cassava land, while the highest is in agroforestry. In addition, total $\mathrm{N}$ in grassland is the lowest, whereas in legume land is the highest compared to other land uses. The contents of POC have closer relationship with total $\mathrm{N}$ than total organic $\mathrm{C}$. It implies that the availability of $\mathrm{N}$ has been more influenced by POC than total organic $\mathrm{C}$. The value of $\mathrm{C} / \mathrm{N}$ ratio is used as indicator for quality of organic matter, where the lower $\mathrm{C} / \mathrm{N}$ ratio the easier decomposition and mineralization of organic matter (Wang et al., 2004). Particulate organic $\mathrm{C}$ constitutes organic $\mathrm{C}$ fraction that is easily mineralized. Cassava land has a lower inorganic $\mathrm{N}$ in comparison to other land uses, where it can be caused by its lower organic matter mineralization and organic $\mathrm{C}$ fraction (Table 2). The low total organic $\mathrm{C}$ and $\mathrm{N}$ in cassava land result in the low biomass returned to the soil and the higher amount of organic C loss due to soil aggregate destruction (Handayani et al., 2012).

The POM fraction, which mainly consists of partially decomposed plant residues, is more influenced by land use and soil management practices than the total SOC pool (Jagadamma and Lal, 2010). The total SOM on the surface horizon of soils under a permanent vegetation cover consists of $15-40 \%$ POM, while on the surface layer of long cultivated cropland soils, it frequently accounts for only less than $10 \%$ of the SOM (Christensen 2001). Differences in POC of different land uses were also found in other studies. A study conducted by Sreekanth et al., (2013) in Inceptisols (sandy clay loam) in the Western Ghat region of Kerala, India, showed that POC concentration on all land use types ranged between 3.9 and $1.6 \%$ (Table 3). Soils of cardamom plantation had the POC value 3.9\% 
which tended to be greater than other land uses. In general, POC concentrations showed the same decline trend as SOC, and POC accounted for 67 to $98 \%$ of total SOC. Declines of SOM can be caused by land cultivation, in which during cultivation, ground clearances may have exposed the soil surface and broken soil aggregates so that the magnitude of erosion and SOC loss increased.

Table 3. Changes in soil organic $\mathrm{C}$ fractions

\begin{tabular}{|c|c|c|c|}
\hline \multirow{2}{*}{ Land use } & POC & SOC & $\mathrm{POC} / \mathrm{SOC}$ \\
\hline & \multicolumn{2}{|c|}{$\%$} & \\
\hline Grassland & 3.50 & 5.2 & 67 \\
\hline Acacia & 3.25 & 4.6 & 71 \\
\hline Cardamom & 3.90 & 4.0 & 98 \\
\hline Open scrub & 2.90 & 3.9 & 74 \\
\hline Pine & 2.64 & 3.51 & 75 \\
\hline Tea & 2.13 & 2.99 & 71 \\
\hline Rubber & 1.90 & 2.40 & 79 \\
\hline Homestead & 1.67 & 1.90 & 88 \\
\hline
\end{tabular}

Source: Sreekanth et al., (2013)

Table 4. Particulate organic matter for three year period with fertilization and crop rotation

\begin{tabular}{lc}
\hline Treatment & Particulate organic C $\left(\mathrm{g} \mathrm{kg}^{-1}\right.$ soil $)$ \\
\hline Year & 3.33 \\
1996 & 3.10 \\
1997 & 2.83 \\
1998 & \\
Fertility treatment & 2.72 \\
Mineral fertilizer & 3.24 \\
N-based manure & 3.45 \\
P-based manure & \\
Crop rotation & 3.79 \\
continuous corn & 2.85 \\
corn-soybean & 2.92 \\
corn followed by 4 yr alfalfa & 3.01 \\
corn-oat-wheat-2 yr red clover hay &
\end{tabular}

Source: Mirsky et al., (2008)

A number of studies on POC in soils in temperate climates also show differences in POC as a result of different land uses and soil management. A study carried out by Mirsky et al., (2005) on Alfisol (silty loam) in Pennsylvania, USA showed that the highest organic $\mathrm{C}$ particulate was found under application of manure fertilizer (dairy manure) and crop rotation and more frequent manure application. The content of POC in the first year is higher than that in the third year, while POC content in the second year did not differ significantly compared to those either in the first or in the third year. The content of POC with inorganic fertilizer was lower (16-21\%) than that in organic fertilizer application (Table 4). Based on their research in a typical subtropical climate, Hubei Province of Central China, $\mathrm{Gu}$ et al., (2016) reported that the application of straw mulch and grass mulch on the soil surface increased significantly the contents of SOC and POC fraction in the soil. Compared to control treatment, the increases of POC in grass mulch and straw mulch treatments in the $0 \pm 40 \mathrm{~cm}$ soil layer were $54.46 \%$ and $37.18 \%$ respectively, while the use 
of straw mulch and grass mulch increased SOC by $15.15 \%$ and $21.14 \%$ respectively.

Conversion a natural forest into monoculture forest plantations causes a decline of SOC and POC. A study done by Yang et al., (2009) in red soils, subtropical climate, Fujian China revealed that the contents of SOC of the surface soils $(0-20 \mathrm{~cm})$ in natural forest (NF), monoculture plantations of Castanopsis kawakamii (CK) and Cunninghamia lanceolata Lamb (CL) were $2.67 \%, 1.73 \%$ and $1.711 \%$ respectively. Moreover, POC was decreased with soil depth, and significantly lower in monoculture plantations of $\mathrm{CK}$ and $\mathrm{CL}$ than in NF (Table 5). This study confirms that a labile fraction (POC) exhibits a more sensitive indicator of SOC change caused by the forest alteration.

Table 5. Distribution of particulate organic carbon for adjasent natural forest and two monoculture plantations of Castanopsis kawakamii (CK) and Cunninghamia lanceolata Lamb

\begin{tabular}{cccc}
\hline $\begin{array}{c}\text { Soil depth } \\
(\mathrm{cm})\end{array}$ & $\begin{array}{c}\text { Natural forest } \\
\left(\mathrm{g} \mathrm{kg}^{-1} \text { soil }\right)\end{array}$ & $\begin{array}{c}\text { Monoculture plantation of } \\
\text { Castanopsis kawakamii } \\
\left(\mathrm{g} \mathrm{kg}^{-1} \text { soil }\right)\end{array}$ & $\begin{array}{c}\text { Monoculture plantation of } \\
\text { Cunninghamia lanceolata Lamb } \\
\left(\mathrm{g} \mathrm{kg}^{-1} \text { soil }\right)\end{array}$ \\
\hline $0-10$ & 11.94 & 5.48 & 2.96 \\
$10-20$ & 6.24 & 3.59 & 1.83 \\
$20-40$ & 1.84 & 1.22 & 0.62 \\
$40-60$ & 1.11 & 0.96 & 0.31 \\
$60-80$ & 0.78 & 0.75 & 0.28 \\
$80-100$ & 0.38 & 0.33 & 0.18 \\
\hline
\end{tabular}

Source: Yang et al., (2009)

The stable fraction of SOM, humic acid also shows changes due to land use differences. Spaccini et al., (2006) reported a decrease in humic substance concentrations in soils due to land use conversion from forest to arable farming. The organic materials protected in the soil aggregates are destroyed by cultivation and undergo microbial oxidation, thus reducing the concentration of SOM (Guimaraes et al., 2013).
A study carried out by Mbagwu and Picollo (2004) in an Ultisol in Umudike, Nigeria under wet tropical rainforest showed that conversion of natural forest to agricultural lands caused a reduction in humic acid concentration, in which decreasing in humic acid was greater than total organic $\mathrm{C}$ (Tabel 6). This decrease was brought about the disintegration of soil aggregates and then SOM was exposed and underwent microbial decomposition.

Table 6. Effect of land use change on soil organic matter fraction in Umudike, Nigeria

\begin{tabular}{lcc}
\hline \multirow{2}{*}{ Land uses } & Total organic C & Humic acid \\
\cline { 2 - 3 } & $\mathrm{g} \mathrm{kg}^{-1}$ & $\mathrm{~g} \mathrm{~kg}^{-1}$ \\
\hline Tropical forest & 23.61 & 15.63 \\
Agricultural land & 6.79 & 2.59 \\
Reduction $(\%)$ & 71 & 83 \\
\hline
\end{tabular}

Source: Mbagwu and Picollo (2004)

The content of humic acids in soils depends on the soil type where soils with relatively high organic $\mathrm{C}$ content such as Histosols contain higher humic acids than mineral soils have. Valladares et al., (2007) found that humic acid fraction in Histosols in
Brazil ranged from $12.5 \mathrm{~g} \mathrm{~kg}^{-1}$ to $208.4 \mathrm{~g} \mathrm{~kg}^{-1}$, while total organic $\mathrm{C}$ contents were $38.0 \mathrm{~g} \mathrm{~kg}-1$ to $528.1 \mathrm{~g} \mathrm{~kg}-1$. Conversely, the mineral soil samples in Idaho, USA investigated by Ghabbour et al., (2012) contained $0.31-9.8 \%$ humic acid. There is no significant difference 
in humic acid contents between forest ecosystem and agroecosystem, which is mainly resulted from manure application (Tobiasova and Miscolczi, 2012). The content of humic acid in organic fertilizer such as compost is relatively high $\left(98.1 \mathrm{~g} \mathrm{~kg}^{-1}\right)$ (Chien et al., 2007).

A wide range of organic materials can be used to increase SOM content in tropical areas. A study on the effect of compost on quality of SOM in Puerto Rico as reported by Rivero et al. (2004) found that addition of 0 , 37,74 and $148 \mathrm{t} \mathrm{ha}^{-1}$ compost increased humic acid during 3 years. However, increase in humic acid was small in comparison to the amount of compost addition. This occurred because compost contained total $\mathrm{C}$ of $168 \mathrm{~g} \mathrm{~kg}^{-}$ 1 , but it only contained $12.2 \mathrm{~g} \mathrm{~kg}^{-1}$ humus. Additionally, the research conducted by Bowden et al., (2010) in Orange Virginia USA, the temperate climate on a silty clay loam (Alfisol) found that application of compost increased total organic $\mathrm{C}$ and humic acid content by $192 \%$ and $364 \%$ respectively compared to without compost application. Equally, in comparison to inorganic fertilizer application, enhancements in total organic $\mathrm{C}$ and humic acid due to compost application were as high as $175 \%$ and $280 \%$ (Table 7 ). Compost application also brought about a rise in soil total N, which indicates the key role of organic matters as $\mathrm{N}$ sources.

Table 7. Effects of treatments on total organic $\mathrm{C}$ and humic acid of soil

\begin{tabular}{|c|c|c|c|}
\hline \multirow{2}{*}{ Treatment } & Total organic $\mathrm{C}$ & Humic acid & Total $\mathrm{N}$ \\
\hline & \multicolumn{3}{|c|}{$\mathrm{g} \mathrm{kg}^{-1}$} \\
\hline Inorganic fertilizer & 17.73 & 1.49 & 0.82 \\
\hline Agronomic rate biosolid compost & 29.5 & 2.6 & 1.59 \\
\hline Agronomic rate poultry litter-yard waste compost & 48.8 & 5.66 & 2.31 \\
\hline Poultry litter & 18.7 & 1.41 & 0.95 \\
\hline $30 \%$ agronomic rate biosolid compost & 20.5 & 1.7 & 0.97 \\
\hline $30 \%$ agronomic rate poultry litter-yard waste compost & 25.1 & 2.33 & 1.21 \\
\hline Unamended control & 16.7 & 1.22 & 0.76 \\
\hline
\end{tabular}

Source: Bowden et al., (2010)

\section{CONCLUSIONS}

In general, dynamics of SOC in tropics is determined by land use changes and soil management practices. Conversion of natural forest into agricultural land uses, monoculture plantations results in a reduction of SOC. Decreases of SOC also occur in lands used for agriculture activities continuously in a longterm without a good land management, which in turn leads to soil degradation. However, restoration of lands of which their SOM have been lost in a great amount can be carried out by a variety of management measures. Changes in SOM as a result of a variety of land uses generally are shown by a decrease in total organic $\mathrm{C}$ in along term. Nevertheless, labile organic C fractions, active fractions in soil have a greater sensitivity in comparison to total organic $\mathrm{C}$ on differences in land uses and management practices in a short time. An agroforestry system has shown a sustainable system and a capacity to increase SOC and soil nutrient especially N. Additionally, in agricultural lands, a variety of inputs such as animal manure, compost, legume crop residue, green plant materials, and plant residue returning to the soil can improve SOM and nutrient. Labile organic fraction (POC) and stable organic $\mathrm{C}$ fraction (humic acid) that constitutes SOM continuum have shown a higher change or more responsive than total organic $\mathrm{C}$ on changes in land uses and soil management practices. The balance between $\mathrm{C}$ inputs and losses determines the accumulation of organic $\mathrm{C}$ in soils.

\section{REFERENCES}

Ahn, M.Y., A. R. Zimmerman, N. B. Comerford, J. O. Sickman, and S. Grunwald. $2009 . \quad$ Carbon 
mineralization and labile organic carbon pools in the sandy soils of a North Florida Watershed. Ecosystems 12: $672-685$.

Ai Dariah, N. L. Nurida and Jubaedah. 2012. The usage of soil conditioner for ameliorating degraded soil dominated by sand and clay fractions. Proceeding of National Seminar on Fertilization Technology and Improvement of Degraded Lands. Pages 669-676. Editors: Wigena I.G.P., N.L. Nurida, D. Setyorini, Husnain, E. Husen dan E. Suryani. Bogor, 29-30 June 2012. Research and Agriculture Development Institute. Agriculture Ministry, Indonesia. 2012. (in Indonesian).

Amusan O.A. and M.T. Adetunji. 2013. Organic matter build-up in a tropical Alfisol under a legume-based integrated nutrient management system. J. Soil Sci. 2(1):29-33.

Anda, M., J. Shamshuddin, C. I. Fauziah and S. R. S. Omar. 2010. Increasing the organic matter content of an Oxisol using rice husk compost: changes in decomposition and its chemistry. Soil Sci. Soc. Am. J. 74:1167-1180.

Baldock, J.A., J.M. Oades, A.G. Waters, X. Peng, A.M. Vassallo, and M.A. Wilson. 1992. Aspects of the chemical structure of soil organic materials as revealed by solid-state 13C NMR spectroscopy. Biogeochemistry 16:142.

Bationo, A., J. Kihara, B. Vanlauwe, B. Waswa and J. Kimetu. 2007. Soil organic carbon dynamics, functions and management in West African agroecosystems. Agricultural Systems, 94(1):13-25.
Bonifacio, E., G. Falsone and M. Petrillo. 2011. Humus forms, organic matter stocks and carbon fractions in forest soils of northwestern Italy. Biol Fertil Soils 47:555-566.

Bowden, C.L., G.K. Evanylo, X. Zhang, E.H. Ervin and J.R. Seiler. 2010. Soil carbon and physiological responses of corn and soybean to organic amendments. Compost Science \& Utility 18:162-173.

Blair, G.J., A. Conteh and R.D.B. Lefroy. 1995. Fate of organic matter and nutrients in upland agricultural systems. In: Lefroy, R.D.B., G.J Blair, E.T. Craswell, (Eds.), Soil Organic Matter Management for Sustainable Agriculture, ACIAR Proceedings No. 56, Ubon, Thailand, August 24-26, 1994. ACIAR, Canberra, Australia, pp. 41-49.

Bruun S., I.K. Thomsen, B.T. Christensen and L.S. Jensen. 2007. In search of stable soil organic carbon fractions: a comparison of methods applied to soils labeled with ${ }^{14} \mathrm{C}$ for 40 days or 40 years. Eur J Soil Sci 59:247-256.

Cahyani, V.R., A. Watanabe, K. Matsuya, S.Asakawa and M. Kimura. 2002. Succession of microbial estimated by phospholipid fatty acid analysis and changes in organic constituents during the composting process of rice straw. Soil Sci. Plant. Nutr. 48:735-743.

Cambardella, C.A. and Elliott, E.T. 1992. Particulate soil organic-matter changes across a grassland cultivation sequence. Soil Sci. Soc. Am. J., 56:777-783.

Chen, C.R., Z.H. Xu, and N.J. Mathers. 2004. Soil carbon pools in adjacent natural and plantation forests of subtropical 
Australia. Soil Sci. Soc. Am. J. 68, 282-291.

Chien, S. W. C., M. C. Wang, C. C. Huang, and K. Seshaiah. 2007. Characterization of humic substances derived from swine manure-based compost and correlation of their characteristics with reactivities with heavy metals. J. Agric. Food Chem. $55,4820-4827$.

Craswell, E.T. and R.D.B. Lefroy. 2001. The role and function of organic matter in tropical soils. Nutrient Cycling in Agroecosystems 61:7-18.

Christensen, B.T. 2001. Physical fractionation of soil and structural and functional complexity in organic matter turnover. Eur J Soil Sci. 52:345-353.

Dechert, G., E. Veldkamp1 and I. Anas. 2004. Is soil degradation unrelated to deforestation? Examining soil parameters of land use systems in upland Central Sulawesi, Indonesia. Plant and Soil 265: 197-209.

de Figueiredo, C.C. , D. V. S. Resck and M. A. C. Carneiro. 2010. Labile and stable fractions of soil organic matter under management systems and native Cerrado. R. Bras. Ci. Solo, 34:907916.

Funakawa, S., M. Makhrawie, and H. B. Pulunggono. 2009. Soil fertility status under shifting cultivation in East Kalimantan with special reference to mineralization patterns of labile organic matter. Plant Soil, 319: 57-66.

Gale , W.J., C.A. Cambardella and T.B. Bailey. 2000. Rootderived carbon and the formation and stabilization of aggregates. Soil Sci. Soc. Am. J., 64: 201-207.
Ghabbour, E.A., G. Davies, J. L. Daggett, Jr., C. A. Worgul, G. A. Wyant and M. Sayedbagheri. 2012. Content of commercial lignites and agricultural top soils in the national soil project. Annals of Environmental Science 6, 112.

Gollany, H.T. , J. M. Novak, Y. Liang, S. L. Albrecht, R. W. Rickman, R. F. Follett, W. W. Wilhelm and P. G. Hunt. 2010. Simulating Soil Organic Carbon Dynamics with Residue Removal Using the CQESTR Model. Soil Sci. Soc. Am. J. 74:372-383.

Grandy, A.S., G.P. Robertson and K.D. Thelen. 2006. Do productivity and environtmental trade-offs justify periodically cultivating no-till cropping systems?. Agron. J. 98:1377-1383.

Greenland D., D. Rimmer and D. Payne. 1975. Determination of the structural stability class of English and Welsh soils, using a water coherence test. European Journal of Soil Science, 26, 294-303.

Gregorich, E.G., M.H., Beare, U.F., McKim and J.O. Skjemstad, 2006. Chemical and biological characteristics of physically uncomplexed organic matter. Soil Sci Soc Am J 70:975-985.

Gu, C., Y. Liu, I. Mohamed, R. Zhang, X. Wang, X. Nie, M. Jiang, M. Brooks, F. Chen, Z. Li. 2016. Dynamic Changes of Soil Surface Organic Carbon under Different Mulching Practices in Citrus Orchards on Sloping Land. PLoS ONE 11(12): e0168384

Guimaraes, D.F., M. I. S. Gonzaga, T. O. da Silva, T. L. da Silva, N. S. Dias and M. I. S. Matias. 2013. Soil organic matter pools and carbon fractions in soil under 
different land uses. Soil \& Tillage Research 126 : 177-182.

Handayani, I.P., P. Prawito and M. Ihsan. 2012. Soil changes associated with Imperata cylindrica grassland conversion in Indonesia. Int. J. Soil Sci. 7(2):61-70.

Haynes, R. J. 2005. Labile organic matter fractions as central components of the quality of agricultural soils: an overview. Adv. Agr., 8, 221-268.

Hermansah, N. Sendi, Yulnafatmawita, T. Masunaga and T. Wakatsuki. 2010. Characteristics and stocks of soil nutrient under various land use types in a super wet tropical rain forest Padang, West Sumatra. J Trop Soils, 15 (1): 5562.

Islam, K.R., and R.R. Weil. 2000. Soil quality indicator properties in mid-Atlantic soils as influenced by conservation management. J. Soil and Water Conserv. 55:69-78.

Jagadamma, S and R. Lal. 2010. Distribution of organic carbon in physical fractions of soils as affected by agricultural management. Biol Fertil Soils (2010) 46:543-554.

Jimenez, J.J., and R. Lal. 2006. Mechanisms of $\mathrm{C}$ sequestration in Soils of Latin america. Critical Reviews in Plant Sciences, 25:337-365.

Krull, E.S., J.A. Baldock and J.O. Skjemstad. 2003. Importance of mechanisms and processes of the stabilization of soil organic matter for modeling carbon turnover. Funct Plant Biol 30:207-222.

Kumar, K. and K.M. Goh. 2000. Crop residues and management practices: effect on soil quality, soil nitrogen dynamics, crop yield and nitrogen recovery. Adv. Agron. 68.

Kursten E. and P. Burschel. 1993. CO2 mitigation by agroforestry. Water, Air Soil Pollut 70:533-544.

Lal, R. 2004. Soil carbon sequestration impacts on global climate change and food security. Science 304:1623-1629.

Lal, R. 2016. Soil health and carbon management. Food and Energy Security, 5(4):212-222.

Ludwig J, D Tongway, D Freudenberger, J Noble and K Hodgkinson. 1997. Landscape Ecology. Function and Management: Principles from Australia's Rangelands. CSIRO, Melbourne.

Mbagwu, J.S.C. and Piccolo, A. 2004. Reduction in organic matter fractions and structural stability following cultivation of tropical forest in Ethiopia and Nigeria. Int. Agrophysics 18:23-29.

Mirsky, S.B., L. E. Lanyon, and B. A. Needelman. 2008. Evaluating soil management using particulate and chemically labile soil organic matter fractions. Soil Sci. Soc. Am. J. 72:180185.

Muscolo, A., M. Sidari, E. Attinà, O. Francioso, V. Tugnoli and S. Nardi. 2006. Biological activity of humic substances is related to their chemical structure. Soil Sci. Soc. Am. J. 71:7585.

Nunan N., M.A. Morgan, J. Scott. and M. Herlihy. 2000. Temporal changes in nitrogen mineralization, microbial biomass, respiration and protease activity in a clay loam soil under ambient temperature Biology and 
Environment: Proceed the Royal Irish Acade 100B: 107-114.

Palm, C.A., C.N., Gachengo, R.J., Delve, G., Cadisch, and K.E., Giller. 2001. Organic inputs for soil fertility management in tropical agroecosystems: application of an organic resource database. Agriculture, Ecosystems and Environment 83, 2742.

Pandey, C.B. , G. B. Singh, S. K. Singh and R. K. Singh. 2010. Soil nitrogen and microbial biomass carbon dynamics in native forests and derived agricultural land uses in a humid tropical climate of India. Plant Soil 333:453-467.

Patricia A. B., P.A.B. Barreto,., E.F. GamaRodrigues,., A. C. Gama-Rodrigues, A.G. Fontes,., J.C. Polidoro, M.K.S. Moco, R.C.R. Machado and V.C. Baligar. 2011. Distribution of oxidizable organic $\mathrm{C}$ fractions in soils under cacao agroforestry systems in Southern Bahia, Brazil. Agroforest Syst. 81:213-220.

Piccolo, M.C., C. Neill and C.C. Cerri. 1994. Net nitrogen mineralization and net nitrification along a tropical foresttopasture chronosequence. Plant Soil 162:61-70.

Quincke, J.A. C.S. Wortmann, M. Marno, T. Franti and R.A. Drijber. 2007. Occasional tillage of no till systems carbon dioxide flux and changes in total and labile soil organic carbon. Agron. J. 99:1158-1168.

Rivero, C. T. Chirenje, L.Q. Ma and G. Martinez. 2004. Influence of compost on soil organic matter quality under tropical conditions. Geoderma 123: 355-361.
Sang, P.M., D. Lamb, M. Bonner and S. Schmidt. 2013. Carbon sequestration and soil fertility of tropical tree plantations and secondary forest established on degraded land. Plant Soil 362:187-200.

Setyawan, D., G. Robert and D. Tongway. 2011. Nutrient cycling index in relation to organic matter and soil respiration of rehabilitated mine sites in Kelian, East Kalimantan. J Trop Soils 16 (3)1: 219223.

Six, J., E.T. Elliott, K. Paustian, and J.W. Doran. 1998. Aggregation and soil organic matter accumulation in cultivated and native grassland soils. Soil Sci. Soc. Am. J. 62:1367-1377.

Six, J., R.T. Conant, E.A. Paul, and K. Panstian. 2002. Stabilization mechanisms of soil organic matter: implications for C-saturation of soils. Plant Soil 241, 151- 176.

Smiley G.L. and J. Kroschel. 2008. Temporal change in carbon stocks of cocoagliricidia agroforests in Central Sulawesi, Indonesia. Agrofor. Syst 73:219-231.

Spaccini, R., A. Piccolo, G. Haberhauer, and M. Gerzabek. 2006. Transformation of organic matter from maize residues into labile and humic fractions of three European soils as revealed by $13 \mathrm{C}$ distribution and CPMAS-NMR spectra. European Journal of Soil Science 51, 583-594.

Sreekanth N.P., S. PrabhaV, B. Padmakumar and A.P Thomas. 2013. Effect of land use conversion on soil carbon storage in a tropical grassland. Annals of Environmental Science 7, 101-112.

Stewart, C.E., C. N. Jason, L.A. Kathryn and P. M. Vitousek. 2011 
Vegetation effects on soil organic matter chemistry of aggregate fractions in a Hawaiian forest. Ecosystems (2011) 14: 382-397.

Strosser, E. 2010. Methods for determination of labile soil organic matter: An overview. J Agrobiol 27(2): 49-60.

Tisdall, J.M., and Oades, J.M. 1982. Organic matter and waterstable aggregates in soils. J. Soil Sci., 33: 141-163.

Tobiasova, E. and J. Miscolczi. 2012. Humus substances and soil structure. Soil Science Annual 63 (3) : 31.36 .

Valladares, G.S., M. G. Pereira, L. H. C. dos Anjos, V. M. Benites, A. G. Ebeling and R. O. Mouta. 2007. Humic substance fractions and attributes of histosols and related high-organic matter soils from Brazil. Communications in Soil Science and Plant Analysis, 38: 763-777.

Verma, B.C., S.P. Datta, R.K. Rattan and A.K. Singh. 2013. Labile and stabilized fractions of soil organic carbon in some intensively cultivated alluvial soils. Journal of Envt. Biology 34:1069-1075.

Wang, W.J., J.A. Baldock, R.C. Dalal and P.W. Moody. 2004. Decomposition of plant materials in relation to nitrogen availability and biochemstry determined by NMR and wet chemical analysis. Soil Biol. Biochem. 36:20452058 .
Wang, Q and S. Wang. 2011. Response of labile soil organic matter to changes in forest vegetation in subtropical regions. Applied Soil Ecology 47: 210-216.

Wijanarko, A., B. H. Purwanto, D. Shiddieq and D. Indradewa. 2012. Effect of organic matter quality and soil fertility on $\mathrm{N}$ mineralization and $\mathrm{N}$ uptake by cassava in Ultisol. J. Perkebunan \& Lahan Tropika, 2 (2):1-14. (in Indonesian).

Yang, Y., J. Guo, G. Chen, Y. Yin, R. Gao and C. Lin. 2009. Effects of forest conversion on soil labile organic carbon fractions and aggregate stability in subtropical China. Plant Soil 323:153-162.

Yonekura, Y., S. Ohta, Y; Kiyono, D. Aksa, K. Morisada, N. Tanaka and M. Kanzaki. 2010. Changes in soil carbon stock after deforestation and subsequent establishment of "Imperata" grassland in the Asian humid tropics. Plant Soil 329:495-507.

Yulnafatmawita, Adrinal and F. Anggriani. 2013. Fresh organic matter application to improve aggregate stability of Ultisols under wet tropical region. $\mathrm{J}$ Trop Soils, 18 ( 1): 33-44.

Zech, W., N. Senesi, G. Guggenberger, K. Kaiser, J. Lehmann, T.M. Miano, A. Miltner and G. Schroth. 1997. Factors controlling humification and mineralization of organic matter in the tropics. Geoderma 79:117-161. 